\title{
PENERAPAN METODE PENEMUAN TERBIMBING PADA MATERI HUBUNGAN ANTAR GARIS DAN SUDUT
}

\author{
Firmansyah $^{1)}$, Maxinus Jaeng ${ }^{2)}$, I Nyoman Murdiana ${ }^{3)}$ \\ Firmansyah_mbs@yahoo.com ${ }^{1)}$, maxjaeng@yahoo.com ${ }^{2)}$, nyomanmur10@yahoo.co.id
}

\begin{abstract}
Abstrak: Tujuan penelitian ini adalah untuk mendeskripsikan penerapan metode penemuan terbimbing yang dapat meningkatkan hasil belajar siswa kelas VIIA SMP Negeri 18 Palu pada materi hubungan antar garis dan sudut. Jenis penelitian yang digunakan adalah penelitian tindakan kelas (PTK). Rancangan penelitian mengacu pada desain penelitian Kemmis dan Mc. Taggart yang terdiri dari empat komponen, 1) perencanaan, 2) tindakan, 3) pengamatan dan 4) refleksi. Jenis data yang digunakan adalah data kualitatif dan data kuantitatif dengan teknik pengumpulan data yaitu observasi, wawancara, catatan lapangan dan tes. Penelitian ini dilakukan dalam dua siklus. Hasil penelitian menunjukkan bahwa penerapan metode pembelajaran penemuan terbimbing dapat meningkatkan hasil belajar siswa dengan mengikuti langkah-langkah metode penemuan terbimbing yaitu: 1) perumusan masalah, peneliti menjelaskan pokok-pokok materi mengenai hubungan antar garis dan sudut, peneliti membagikan lembar kegiatan peserta didik yang berisi pertanyaan menyangkut materi hubungan antar garis dan sudut yang harus diselesaikan oleh siswa. 2) pemrosesan data dan penyusunan konjektur, siswa memproses data yang ada dalam lembar kegiatan peserta didik dan menyusun konjektur. 3) pemeriksaan konjektur, peneliti memeriksa konjektur yang telah disusun oleh siswa dan memberikan bimbingan seperlunya apabila terdapat kesalahan dalam menyusun konjektur. 4) verbalisasi konjektur, siswa perwakilan dari masing-masing kelompok mempersentasikan hasil konjektur yang diperoleh dan peneliti membimbing siswa untuk membuat kesimpulan yang benar mengenai materi hubungan antar garis dan sudut. 5) umpan balik, memberikan soal latihan mengenai materi hubungan antar garis dan sudut kepada siswa. Hasil penelitian ini menunjukkan bahwa ketuntasan belajar klasikal siswa pada siklus I 50\% dan mengalami peningkatan pada siklus II yaitu 77\%.
\end{abstract}

Kata kunci: Metode Pembelajaran Penemuan Terbimbing, Hasil Belajar, Garis dan Sudut.

\begin{abstract}
Abstrak: The purpose of this study is to describe the application of guided discovery method that can improve student learning outcomes VII A grade SMPN 18 Palu on the material connection between lines and angles. The type of research used is classroom action research $(C A R)$. The research design refers to the research design of Kemmis and Mc. Taggart consists of four components: 1) planning, 2) action, 3) observation and 4) reflection. The type of data used is qualitative data and quantitative data with data collection techniques are observation, interviews, field notes and tests. This research was conducted in two cycles. The results showed that the application of guided discovery learning methods can improve student learning outcomes by following the steps of guided discovery methods are: 1) the formulation of the problem, the researcher explains the subject matter regarding the relationship between lines and angles, the researcher distributes student activity sheet which contains questions concerning the material relations between lines and angles that must be completed by students. 2) data processing and constructing conjectures, students process data in the student activity sheet and arrange conjectures. 3) Examining the conjecture, the researcher examines the conjectures that have been prepared by students and provides guidance as needed if there is an error in compiling the conjecture. 4) verbalizing the conjecture, student representatives from each group present the results of the conjecture obtained and the researcher guides students to make correct conclusions about the material relations between lines and angles. 5) feedback, giving practice questions about the material of relationships between lines and angles to students. The results of this study indicate that classical learning completeness students in the cycle I is 50\% and increased in the cycle II is $77 \%$.
\end{abstract}

Keywords: Guided Discovery Learning Methods, Learning Outcomes, Lines and Angles. 
Matematika merupakan ilmu universal yang mendasari perkembangan teknologi modern, matematika mempunyai peran penting dalam berbagai disiplin ilmu dan memajukan daya pikir manusia (Depdiknas, 2006:9). Oleh karena itu matematika perlu diajarkan sejak seorang anak duduk di bangku Sekolah Dasar sampai perguruan tinggi untuk membekali mereka dengan kemampuan berpikir logis, analitis, sistematis, kritis dan kreatif serta kemampuan bekerja sama. Salah satu tujuan matematika berdasarkan kurikulum 2013 adalah dapat mendorong dan menginspirasi peserta didik agar mampu memahami, menerapkan dan mengembangkan pola berpikir yang rasional dan objektif dalam merespon substansi atau materi pembelajaran matematika (Suwarsono, 2013: 7).

Geometri merupakan satu materi pelajaran matematika yang memiliki peran sangat penting dalam kehidupan. Tujuan dari pembelajaran geometri yaitu untuk menimbulkan rasa percaya diri siswa mengenai kemampuan matematikanya, sebagai landasan agar dapat memecahkan masalah dengan baik, dapat bernalar dan berkomunikasi secara sistematika (Ufi, 2017: 1). Hal ini menunjukkan bahwa betapa pentingnya bagi siswa untuk dapat memahami konsep-konsep dasar dari geometri.

Menurut Sunardi (Ufi, 2017: 1), pada dasarnya geometri cukup mudah untuk dapat dipahami siswa jika dibandingkan dengan cabang matematika lainnya, karena benda-benda geometri dapat dijumpai oleh siswa pada lingkungan sekitarnya. Namun kenyataannya, sebagian besar siswa kurang memahami konsep geometri, bahkan mereka kurang tertarik belajar matematika. Hal ini karena mereka menganggap bahwa pelajaran matematika merupakan pelajaran yang sulit untuk dimengerti atau dipahami, karena dalam penyelesaiannya soal-soal matematika menggunakan rumus-rumus matematika dan perhitungan. Siswa diharapkan dapat membangun pemahamannya sendiri melalui pengetahuan yang sudah dimilikinya yaitu dengan mengaitkan pengetahuannya tersebut dengan konsep-konsep yang diberikan. Oleh karena itu, peran guru sangat penting sebagai satu komponen pembelajaran yang mampu memilih model, metode, strategi maupun pendekatan yang tepat pada materi yang akan diajarkan sehingga dapat memberikan pemahaman yang baik kepada siswa dan mencapai hasil yang diinginkan.

Hal yang serupa juga terjadi di SMP Negeri 18 Palu, sebagian besar siswa kurang memahami konsep geometri. Berdasarkan hasil wawancara dengan guru mata pelajaran matematika di kelas VII SMP Negeri 18 Palu diperoleh informasi bahwa masih banyak siswa yang mengalami kesulitan pada mata pelajaran matematika. Materi yang sulit dipahami oleh siswa yaitu hubungan antar garis dan sudut. Guru tersebut mengungkapkan bahwa telah digunakan beberapa metode pada proses pembelajaran. Metode yang digunakan yaitu metode ceramah, pembelajaran langsung, memberi contoh dan latihan. Terkadang guru menggunakan media pembelajaran dan melakukan proses pembelajaran secara berkelompok kepada siswa agar siswa lebih paham dan saling bekerja sama satu sama lain, namun hasilnya belum sesuai dengan yang diharapkan.

Selanjutnya guru tersebut mengungkapkan bahwa materi hubungan antar garis dan sudut merupakan materi yang dianggap sulit oleh siswa kelas VII SMP Negeri 18 Palu, siswa tidak menguasai konsep sudut jika dua garis sejajar dipotong oleh garis lain, siswa belum mampu menentukan sifat-sifat sudut yang terbentuk dan belum mampu menggunakan hubungan sifat-sifat sudut yang terbentuk dalam menentukan besar sudut, sehingga menyebabkan rendahnya hasil belajar siswa.

Selain itu peneliti juga melakukan observasi terhadap guru dan siswa pada saat proses pembelajaran di kelas. Berdasarkan observasi tersebut, terlihat bahwa ketika guru melakukan apersepsi dengan bertanya kepada siswa mengenai materi penjumlahan dan pengurangan bilangan bulat yang telah diajarkan pada pertemuan sebelumnya, kebanyakan 
siswa lupa dengan materi tersebut. Hal ini diakibatkan ada kecenderungan informasi yang diterima mudah lupa. Selain itu juga, dalam proses pembelajaran siswa kurang berinteraksi dengan guru maupun sesama teman. Hal ini disebabkan guru tidak melibatkan siswa secara aktif untuk menemukan konsep secara mandiri, dan juga guru tidak memberikan kesempatan kepada siswa untuk bertanya mengenai materi maupun konsep yang diajarkan, sehingga kebanyakan siswa merasa bosan dan kesulitan saat mengerjakan soal yang diberikan guru. Tanpa pemahaman yang cukup dan bimbingan dari guru untuk menemukan konsep secara mandiri, siswa pasti mengalami kesulitan jika mengerjakan soal yang divariatifkan atau dimodifikasi.

Menindaklanjuti temuan dari hasil wawancara dan pengamatan awal maka dilaksanakan tes identifikasi kepada siswa Kelas VIIIB. Pemberian tes identifikasi kepada siswa kelas VIII dengan alasan, karena siswa tersebut telah mempelajari materi hubungan antar garis dan sudut. Siswa yang mengikuti tes identifikasi sebanyak 22 siswa. Adapun soal yang diberikan ditunjukkan pada gambar 1 .

1. Perhatikan gambar di bawah ini:

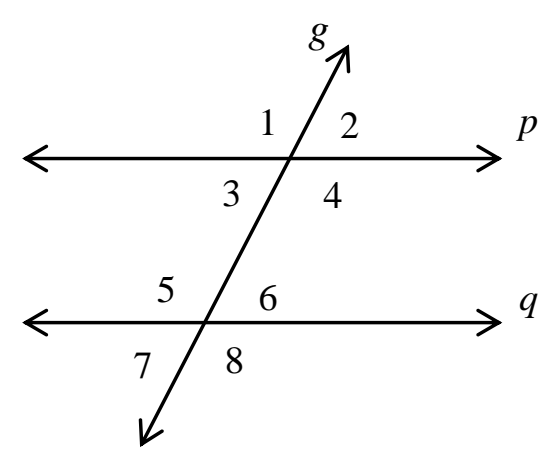

Berdasarkan gambar 1, diketahui garis $p$ sejajar dengan garis $q$, kemudian garis-garis tersebut dipotong oleh sebuah garis $g$. Tentukan:

a. Pasangan sudut-sudut sehadap

b. Pasangan sudut-sudut luar bersebrangan

c. Pasangan sudut-sudut dalam bersebrangan

d. Pasangan sudut-sudut dalam sepihak

e. Pasangan sudut-sudut luar sepihak.

Gambar 1. Garis $p / / q$ dan dipotong oleh garis $g$

Setelah melakukan tes, peneliti menganalisis jawaban siswa. Bentuk jawaban siswa dapat dilihat pada gambar 2 .

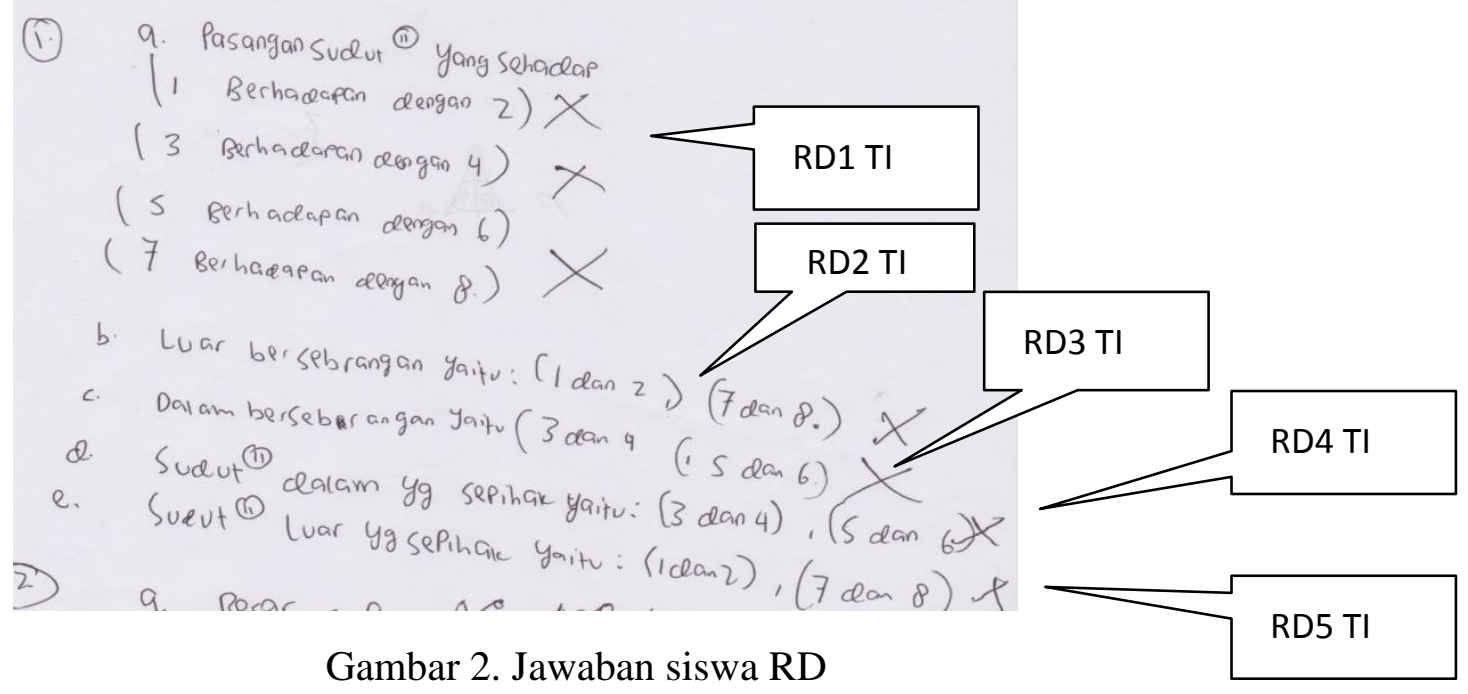

Berdasarkan gambar 2, pada bagian a, siswa belum dapat menentukan sudut sehadap (RD1 TI). Jawaban yang seharusnya adalah sudut- sudut sehadap yaitu $\angle 1$ dan $\angle 5$, $\angle 2$ dan $\angle 6, \angle 3$ dan $\angle 7, \angle 4$ dan $\angle 8$. Pada bagian b, siswa belum dapat menentukan sudut- 
sudut dalam bersebrangan (RD2 TI). Jawaban yang seharusnya adalah sudut-sudut dalam bersebrangan yaitu $\angle 3$ dan $\angle 6, \angle 4$ dan $\angle 5$. Pada bagian c, siswa belum dapat menentukan sudut-sudut luar bersebrangan (RD3 TI). Jawaban yang seharusnya adalah sudut-sudut luar bersebrangan yaitu $\angle 2$ dan $\angle 7, \angle 1$ dan $\angle 8$. Pada bagian d, siswa belum dapat menentukan sudut-sudut dalam sepihak (RD4 TI). Jawaban yang seharusnya adalah sudut-sudut dalam sepihak yaitu $\angle 4$ dan $\angle 6, \angle 3$ dan $\angle 5$. Pada bagian e, siswa belum dapat menentukan sudutsudut luar sepihak (RD5 TI). Jawaban yang seharusnya adalah sudut-sudut luar sepihak yaitu $\angle 2$ dan $\angle 8, \angle 1$ dan $\angle 7$.

Berdasarkan jawaban siswa tersebut, terlihat bahwa siswa tidak memahami materi hubungan antar garis dan sudut yaitu jika dua garis sejajar dipotong oleh garis lain. Siswa masih kesulitan dalam menentukan pasangan sudut yang terbentuk jika dua garis sejajar dipotong oleh garis lain.

Berdasarkan permasalahan tersebut, maka perlu diterapkan suatu metode pembelajaran yang dapat mendorong siswa untuk berfikir sendiri dengan bantuan dari guru maupun teman sebaya dan dapat melibatkan siswa secara aktif dalam kegiatan belajar mengajar guna meningkatkan hasil belajar siswa. Metode pembelajaran yang sesuai dengan permasalahan di atas adalah metode penemuan terbimbing.

Menurut hamalik (Yusnawan, 2013: 77), metode penemuan terbimbing yaitu suatu prosedur mengajar yang menitikberatkan studi individual, manipulasi objek-objek dan eksperimen oleh siswa sebelum membuat generalisasi sampai siswa menyadari suatu konsep. Siswa melakukan penemuan sedangkan guru membimbing siswa ke arah yang tepat. Bimbingan dilakukan melalui serangkaian pertanyaan atau Lembar Kegiatan Peserta Didik (LKPD). Bimbingan yang diberikan guru sesuai dengan kemampuan siswa dan materi yang dipelajari. Penerapan metode penemuan terbimbing ini diharapkan dapat membimbing siswa dalam menentukan sudut-sudut yang terbentuk jika dua garis sejajar dipotong oleh garis lain. Dalam metode ini siswa mendapatkan bantuan atau bimbingan dari guru untuk menyelesaikan soal yang diberikan, yang mana guru mengarahkan siswa untuk mendapatkan jawabannya melalui tahap demi tahap, sehingga siswa menemukan sendiri jawabannya dan dapat mengkonstruksikan sendiri pemahaman yang dimilikinya. Dengan ini diharapkan pemahaman siswa dapat bertahan lama dan mudah diingat.

Berdasarkan uraian di atas, peneliti termotivasi untuk melakukan penelitian yang berjudul "penerapan metode penemuan terbimbing untuk meningkatkan hasil belajar siswa kelas VIIA SMP Negeri 18 Palu pada materi hubungan antar garis dan sudut".

\section{METODE PENELITIAN}

Jenis penelitian yang digunakan dalam penelitian ini adalah penelitian tindakan kelas yang mengacu pada desain penelitian yang dikembangkan oleh Kemmis dan Mc. Taggart yang terdiri atas empat tahap yaitu perencanaan tindakan, pelaksanaan tindakan, observasi,dan refleksi. Subjek penelitian ini adalah seluruh siswa/siswi kelas VIIA SMP Negeri 18 Palu yang banyaknya 22 siswa. Terdapat 3 informan yang dipilih berdasarkan tingkat kemampuan tinggi, sedang dan rendah yaitu HZ (siswa berkemampuan tinggi), FA (siswa berkemampuan sedang), MAS (siswa berkemampuan rendah) Pemilihan informan berdasarkan perolehan tes awal serta rekomendasi guru bidang studi matematika di kelas VIIA SMP Negeri 18 Palu.

Teknik pengumpulan data pada penelitian ini meliputi data kualitatif dan data kuantitatif. Data kualitatif dilakukan dengan 3 cara yaitu observasi, wawancara, dan 
catatan lapangan. Data kuantitatif diperoleh dengan memberikan tes tertulis yaitu: tes awal dan tes akhir tindakan. Analisis data dilakukan dengan mengacu pada analisis data kualitatif model Miles (Cendana, 2016: 34) yaitu: (a) reduksi data (Data Reduction), (b) penyajian data (Data Display) dan (c) kesimpulan (Conclusion). Keberhasilan tindakan dapat diketahui dari hasil tes tertulis siswa, aktivitas guru dalam mengelola pembelajaran dan aktivitas siswa dalam mengikuti pembelajaran. Data aktivitas guru dan siswa pada setiap siklus minimal berkategori baik atau sangat baik untuk setiap aspek pada lembar observasi dan data hasil belajar siswa dikatakan meningkat apabila telah memenuhi kriteria ketuntasan minimal (KKM) yang berlaku di SMP Negeri 18 Palu yaitu mencapai nilai $\geq 75$.

\section{HASIL PENELITIAN}

Penelitian diawali dengan memberikan tes awal kepada siswa sebelum memasuki materi pembelajaran yaitu hubungan antar garis dan sudut yang bertujuan untuk mengetahui kemampuan awal siswa, sehingga menjadi pedoman menentukan kelompok belajar heterogen dan informan dalam penelitian. Materi tes awal yang diberikan adalah menentukan jenis-jenis sudut, besar sudut yang terbentuk dari hubungan beberapa garis yang berpotongan, garis vertikal, garis horizontal dan garis sejajar. Tes awal diikuti oleh seluruh siswa kelas VIIA SMP Negeri 18 Palu sebanyak 22 siswa. Berdasarkan hasil analisis tes awal dan diskusi dengan guru, peneliti membentuk 5 kelompok belajar dengan pertimbangan kemampuan akademik dan jenis kelamin. Setiap kelompok terdiri dari 4 sampai 5 siswa. Selanjutnya peneliti bersama guru matematika VIIA SMP Negeri 18 Palu menentukan informan sebanyak 3 siswa. Hasil analisis tes awal menunjukkan bahwa dari 22 siswa yang mengikuti tes, terdapat 5 siswa yang tuntas atau telah mencapai nilai ketuntasan belajar, sedangkan 17 siswa lainnya tidak tuntas atau belum mencapai nilai ketuntasan belajar. Hal ini dikarenakan siswa belum belum bisa menentukan jenis-jenis sudut dari gambar sudut yang diberikan, dan siswa belum dapat menentukan besar salah satu sudut apabila sudut lain diketahui.

Penelitian ini terdiri atas dua siklus. Setiap siklus dilaksanakan dalam dua kali pertemuan dengan rincian pertemuan pertama untuk pelaksanaan tindakan dan pertemuan kedua untuk tes akhir tindakan. Materi pada siklus I adalah menemukan konsep sudut yang terbentuk jika dua garis sejajar dipotong oleh garis lain (garis transversal), sedangkan materi pada siklus II adalah sifat-sifat sudut yang terbentuk jika dua garis sejajar dipotong oleh garis lain serta penggunaannya. Pelaksanaan tindakan dilakukan dalam tiga kegiatan yaitu: a) kegiatan awal, b) kegiatan inti dan c) kegiatan penutup. Setiap tahapan pelaksanaan pembelajaran pada kegiatan inti memuat langkah-langkah metode penemuan terbimbing yaitu: perumusan masalah, pemrosesan data, penyusunan konjektur, pemeriksaan konjektur, verbalisasi konjektur dan umpan balik.

Kegiatan awal diawali peneliti dengan menyiapkan siswa untuk belajar dan membuka pembelajaran dengan salam dan mengajak siswa untuk berdo'a serta mengecek kehadiran siswa. Selanjutnya peneliti memberikan informasi tentang materi ajar dan menyampaikan tujuan pembelajaran yang hendak dicapai setelah mempelajari materi hubungan antar garis dan sudut. Adapun tujuan pembelajaran siklus I yaitu siswa dapat menemukan konsep sudut yang terbentuk jika dua garis sejajar dipotong oleh garis transversal. Tujuan pembelajaran siklus II yaitu siswa dapat menemukan sifat-sifat sudut yang terbentuk jika dua garis sejajar dipotong oleh garis lain dan siswa dapat menggunakan sifat-sifat sudut yang terbentuk jika dua garis sejajar dipotong oleh garis lain dengan menentukan besar sudut. Selanjutnya peneliti memotivasi siswa dengan cara menyampaikan manfaat mempelajari materi hubungan 
antar garis dan sudut. Peneliti menyampaikan bahwa konsep materi hubungan antar garis dan sudut digunakan dalam menentukan besar sudut pada suatu bangun datar misalnya segitiga, persegi dan lain-lain. Kegiatan pembelajaran dilanjutkan dengan pemberian apersepsi yaitu mengajukan pertanyaan untuk mengingatkan kembali materi prasyarat. Apersepsi tersebut mengenai jenis-jenis sudut dan garis sejajar yang telah dipelajari pada pertemuan sebelumnya. Selanjutnya peneliti membagi siswa kedalam 5 kelompok yang sudah ditentukan sebelumnya oleh peneliti sesuai dengan hasil tes awal.

Kegiatan inti dimulai dengan perumusan masalah yaitu memberikan informasi pokokpokok materi hubungan antar garis dan sudut. Pada siklus I yaitu konsep sudut yang terbentuk jika dua garis sejajar dipotong oleh garis lain seperti sudut sehadap, sudut dalam berseberangan, sudut luar berseberangan, sudut dalam sepihak dan sudut luar sepihak. Pada siklus II yaitu menemukan sifat-sifat sudut yang terbentuk jika dua garis sejajar dipotong oleh garis lain serta penggunaan sifat-sifat tersebut dalam menentukan besar sudut. Selanjutnya peneliti membagikan LKPD yang berisi pertanyaan menyangkut materi ajar. Selanjutnya guru menjelaskan hal-hal yang akan dilakukan dalam LKPD tersebut dan mempersilahkan siswa untuk mengisi LKPD yang sudah dibagikan.

Langkah pemrosesan data dan penyusunan konjektur dilakukan dengan siswa mulai menganalisis data yang diberikan serta menyusun dugaan sementara (konjektur) dengan anggota kelompoknya. Peneliti mengamati dan mengawasi agar setiap kelompok aktif dan bekerja sama dalam mengerjakan LKPD tersebut serta membimbing siswa yang masih mengalami kesulitan dalam menganalisis dan menyusun konjektur. Hasil yang diperoleh pada siklus I yaitu siswa dalam tiap kelompok telah mengerjakan LKPD dengan baik setelah menerima bimbingan dari peneliti dan guru matematika. Meskipun ada beberapa siswa yang belum aktif dalam kelompoknya. Hal ini disebabkan siswa tersebut malas dalam mengerjakan LKPD tersebut, sedangkan pada siklus II, siswa sudah terlibat aktif dalam kelompoknya saat mengerjakan LKPD. Siswa berani bertanya kepada peneliti mengenai apa yang mereka belum pahami sehingga peneliti dapat memberikan bimbingan kepada kelompok tersebut

Langkah pemeriksaan konjektur dilakukan peneliti dan guru matematika dengan cara berkeliling memeriksa konjektur yang telah disusun oleh siswa pada masing-masing kelompok. Pada siklus I, peneliti menemukan konjektur yang disusun oleh salah satu kelompok masih terdapat kesalahan yaitu dalam membuat kesimpulan mengenai sudut sehadap sehingga peneliti mengarahkan dan membimbing kelompok tersebut dalam menemukan jawaban yang benar mengenai kesalahan yang dialami kelompok tersebut. Pada siklus II, hampir semua kelompok sudah bisa mengerkan LKPD dengan benar. Hasil yang diperoleh pada siklus I yaitu siswa sudah dapat menyusun kembali konjektur yang benar setelah peneliti dan guru matematika memeriksa hasil konjektur yang telah disusun. Siswa sudah mengetahui kesalahan dalam mengerjakan LKPD tersebut sehingga mampu menyusun konjektur yang benar. Pada siklus II, siswa juga telah mampu menyusun konjektur yang benar setelah peneliti dan guru matematika memeriksa dan memberikan bimbingan kepada masing-masing kelompok.

Langkah verbalisasi konjektur dilakukan peneliti dengan meminta anggota tiap kelompok untuk mempersentasikan hasil kerja kelompoknya dan memberikan kesempatan kepada kelompok lain untuk bertanya kepada kelompok yang telah mempersentasikan hasil kerja kelompoknya. Hasil yang didapat pada siklus I yaitu siswa sudah berani dalam mempersentasikan meskipun tidak semua kelompok mempersentasikan hasil kerja kelompoknya dan memberi tanggapan kepada kelompok lain, sedangkan pada siklus II, 
semua kelompok telah berani mempersentasikan hasil kerja kelompoknya dan memberikan tanggapan kepada kelompok lain serta dapat menyimpulkan materi yang telah diajarkan.

Langkah umpan balik dilakukan peneliti dengan memberikan soal latihan kepada semua siswa. Soal latihan pada siklus I yaitu mengenai konsep sudut yang terbentuk jika dua garis sejajar dipotong oleh garis lain, sedangkan pada siklus II mengenai sifat-sifat sudut yang terbentuk jika dua garis sejajar dipotong oleh garis lain serta penggunaan sifatsifat tersebut dalam menyelesaikan soal atau menentukan besar sudut. Hasil yang diperoleh yaitu siswa antusias dalam mengerjakan soal latihan tersebut. Hal ini dapat dilihat dari hasil pekerjaan siswa terhadap soal latihan tersebut. Pada siklus I terdapat 15 siswa yang tuntas dari 22 siswa yang mengerjakan soal latihan, sedangkan pada siklus II terdapat 20 siswa yang tuntas dari 22 siswa yang mengerjakan soal latihan.

Hasil tes akhir tindakan yang diperoleh pada siklus I menunjukan bahwa dari 22 siswa yang mengikuti tes, terdapat 11 siswa yang tuntas atau memperoleh nilai $\geq 75$ dan 11 siswa yang tidak tuntas atau memperoleh nilai $<75$. Presentase ketuntasan belajar klasikal yang dicapai adalah 50\%, belum mencapai persentase ketuntasan belajar klasikal minimum yaitu $75 \%$.

Hasil tes akhir yang diperoleh pada siklus II menunjukan bahwa dari 22 siswa yang mengikuti tes, terdapat 17 siswa yang memperoleh nilai $\geq 75$ atau dikategorikan tuntas dan 5 siswa yang tidak tuntas atau mendapat nilai $<75$. Presentase ketuntasan belajar klasikal yang dicapai adalah $77 \%$. Persentase tersebut sudah mencapai persentase ketuntasan belajar klasikal minimum yaitu $75 \%$.

Aspek yang diamati pada lembar observasi aktivitas guru yaitu sebanyak 23 aspek berdasarkan rancangan pelaksanaan pembelajaran (RPP). Hasil observasi aktivitas guru pada siklus I menunjukan bahwa pembelajaran dengan menerapkan metode penemuan terbimbing sudah baik. Hal ini terlihat dari skor nilai pengamatan yaitu 92, namun masih ada beberapa hal yang perlu diperbaiki pada kegitan pembelajaran selanjutnya yaitu pemberian informasi pokok-pokok materi yang akan dipelajari serta pengelolaan waktu dalam proses pembelajaran. Pada siklus II hasil observasi yang diperoleh terhadap aktivitas guru menunjukkan bahwa pembelajaran dengan menerapkan metode penemuan terbimbing sudah dilaksanakan dengan baik. Hal ini ditunjukkan dengan jumlah nilai pengamatan yaitu 109.

Aspek yang diamati pada lembar observasi aktivitas siswa yaitu sebanyak 23 aspek berdasarkan rancangan pelaksanaan pembelajaran (RPP). Hasil observasi aktivitas siswa pada siklus I menunjukkan bahwa pembelajaran dengan menggunakan metode penemuan terbimbing sudah baik. Hal ini terlihat dari skor nilai pengamatan yaitu 91, sedangkan pada siklus siklus II menunjukkan bahwa dengan menerapkan pembelajaran dengan metode penemuan terbimbing sudah baik, dengan skor nilai pengamatan yaitu 106.

\section{PEMBAHASAN}

Penelitian ini merupakan Penelitian Tindakan Kelas (PTK) yang bertujuan untuk meningkatkan hasil belajar siswa kelas VIIA SMP Negeri 18 Palu pada materi hubungan antar garis dan sudut. Penelitian ini dilakukan melalui dua siklus, setiap siklus terdiri atas 4 komponen yaitu: (1) perencanaan, (2) pelaksanaan tindakan, (3) observasi dan (4) refleksi, seperti yang dikemukakan oleh Kemmis dan Mc. Taggart (Arikunto, 2007: 16).

Sebelum pelaksanaan tindakan, peneliti terlebih dahulu memberikan tes awal kepada siswa untuk mengetahui kemampuan awal siswa. Hal ini sesuai dengan pendapat Sutrisno (2012) yang menyatakan bahwa pelaksanaan tes sebelum perlakuan dilakukan untuk 
mengetahui pemahaman awal siswa. Selain itu, hasil tes awal juga digunakan untuk menentukan informan dan pembentukan kelompok belajar yang heterogen.

Peneliti menerapkan metode penemuan terbimbing pada pelaksanaan tindakan baik siklus I maupun siklus II agar dapat mengaktifkan siswa dalam pembelajaran dan dapat menemukan sendiri konsep yang dipelajari. Sebagaimana yang dikemukakan oleh Yulia (2010: 3) bahwa melalui metode penemuan terbimbing, siswa dapat berpartisipasi aktif dalam pembelajaran, meningkatkan kemampuan pemecahan masalah siswa dan menjadikan pengetahuan yang diperoleh lebih lama membekas dalam ingatan siswa karena mereka dilibatkan langsung langsung dalam proses menemukan.

Pembelajaran dengan metode penemuan terbimbing dapat dilakukan secara individu maupun kelompok. Hal ini sesuai dengan pendapat Markaban (2006: 17) yang menyatakan bahwa pembelajaran dengan metode penemuan terbimbing dapat diselenggarakan secara individu atau kelompok. Dalam pelaksanaannya, peneliti membentuk beberapa kelompok belajar, peneliti mengelompokkan siswa kedalam 5 kelompok yang masing-masing beranggotakan 4 - 5 siswa. Tujuan dari pengelompokkan ini yaitu untuk memudahkan siswa dalam mengkomunikasikan ide-ide matematisnya kepada teman kelompoknya dan bisa bekerja sama. Hal ini sejalan dengan pendapat Nurcholis ( 2013: 69) bahwa belajar kelompok bertujuan untuk mengefisienkan waktu dalam belajar, melatih siswa untuk bekerja sama dan bertanggung jawab dalam kelompoknya, menumbuhkan rasa kebersamaan dan saling tolong menolong serta menambah kedekatan dengan teman sekelasnya.

Peneliti juga memberikan LKPD kepada masing-masing kelompok yang bertujuan untuk menunutun dan mendorong siswa dalam proses penemuan serta dapat mengembangkan kreativitas siswa dalam belajar, sehingga dapat menuntun siswa untuk dapat menarik kesimpulan terhadap materi yang diajarkan. Hal ini sesuai dengan pendapat Trianto (2009: 22) yang menyatakan bahwa LKS/LKPD adalah panduan siswa yang digunakan untuk melakukan penyalidikan atau pemecahan masalah.

Langkah-langkah penemuan terbimbing yang digunakan dalam proses pembelajaran yaitu perumusan masalah, pemrosesan data, penyusunan konjektur, pemeriksaan konjetur, verbalisasi konjektur dan umpan balik. Hal ini sejalan dengan pendapat Widdiharto (Yulia, 2010: 11) yang menyatakan bahwa agar pelaksanaan metode penemuan terbimbing dapat berjalan dengan efektif, beberapa langkah yang ditempuh oleh guru matematika yaitu 1) perumusan masalah; perumusan masalah harus jelas dengan menghindari pertanyaanpertanyaan yang dapat mengakibatkan kesalahan penafsiran bagi para siswa sehingga arah yang ditempuh siswa tidak salah, 2) pemrosesan data; siswa menyusun, mengorganisir, dan menganalisis masalah yang diberikan oleh guru, 3) penyusunan konjektur; siswa menyusun dugaan sementara atau prakiraan dari hasil analisis yang dilakukan, 4) pemeriksaan konjetur; guru memeriksa konjektur atau dugaan sementara yang telah dibuat oleh siswa, yaitu memeriksa jawaban yang telah diberikan siswa dari pertanyaan-pertanyaan yang ada di LKPD, 5) verbalisasi konjektur; verbalisasi konjektur ini merupakan pengungkapan dan penjelasan kembali dengan kata-kata kebenaran jawaban yang diberikan oleh siswa, agar siswa dapat membuat kesimpulan dan 6) umpan balik; guru menyediakan soal latihan atau soal tambahan untuk memeriksa apakah hasil penemuan yang dilakukan siswa itu benar.

Berdasarkan hasil tes akhir tindakan siklus I diperoleh bahwa jumlah siswa yang mampu menyelesaikan soal yang berkaitan dengan konsep sudut yang terbentuk jika dua garis sejajar dipotong oleh garis lain atau dikategorikan tuntas yaitu 11 siswa dari 22 siswa yang mengikuti tes akhir tindakan siklus I dengan persentase ketuntasan belajar klasikal siswa adalah 50\%, sedangkan pada siklus II diperoleh bahwa dari 22 siswa yang mengikuti 
tes, terdapat 17 siswa yang tuntas dengan persentase ketuntasan belajar klasikal sebesar $77 \%$. Hal ini menunjukkan siswa mampu menyelesaikan soal yang berkaitan dengan sifatsifat sudut yang terbentuk jika dua garis sejajar dipotong oleh garis lain serta penggunaan sifat-sifat sudut tersebut.

Berdasarkan hasil observasi yang dilakukan pengamat diperoleh informasi bahwa dalam pelaksanaan pembelajaran dengan menerapkan metode penemuan terbimbing pada umumnya aktivitas guru maupun siswa menunjukkan peningkatan dari siklus I ke siklus II. Peningkatan dapat dilihat dari hasil observasi aktivitas guru dan hasil observasi aktivitas siswa pada siklus I, dari lembar observasi aktivitas guru diperoleh bahwa skor nilai pengamatan sebesar 92 dengan kriteria baik, sedangkan untuk lembar observasi aktivitas siswa diperoleh skor nilai pengamatan 91 dengan kriteria baik, sehingga aktivitas guru selama pembelajaran berada dalam kategori baik dan aktivitas siswa selama pembelajaran berada juga dalam kategori baik, sedangkan pada hasil observasi aktivitas guru dan hasil observasi aktivitas siswa pada siklus II, dari lembar observasi aktivitas guru diperoleh bahwa skor nilai pengamatan sebesar 109 dengan kriteria sangat baik, sedangkan untuk lembar observasi aktivitas siswa diperoleh skor nilai pengamatan sebesar 106 dengan kriteria sangat baik, sehingga aktivitas guru selama pembelajaran berada dalam kategori sangat baik dan aktivitas siswa selama pembelajaran berada dalam kategori sangat baik. Berdasarkan hal tersebut diketahui bahwa kriteria keberhasilan tindakan telah tercapai yang mana setiap indikator pada proses pelaksanaan pembelajaran telah tercapai.

\section{KESIMPULAN}

Berdasarkan hasil dan pembahasan dalam penelitian maka dapat disimpulkan bahwa penerapan metode pembelajaran penemuan terbimbing dapat meningkatkan hasil belajar siswa kelas VII A SMP Negeri 18 Palu pada materi hubungan antar garis dan sudut melalui langkah-langkah sebagai berikut; 1) perumusan masalah, 2) pemrosesan data, 3) penyusunan konjektur, 4) pemeriksaan konjektur, 5) verbalisasi konjektur dan 6) umpan balik.

Kegiatan awal yang dilakukan yaitu peneliti membuka pembelajaran dan mempersiapkan siswa untuk belajar, meminta siswa untuk berdo'a bersama dan mengecek kehadiran siswa. Setelah berdo'a dan mengecek kehadiran siswa, peneliti memberikan informasi mengenai materi yang akan diajarkan dan tujuan pembelajaran yang hendak dicapai, memotivasi siswa, memberikan apersepsi kemudian membentuk siswa kedalam beberapa kelompok.

Kegiatan inti memuat langkah-langkah yaitu: 1) perumusan masalah; guru membagikan LKPD yang berisi masalah berupa pertanyaan-pertanyaan mengenai materi hubungan antar garis dan sudut kepada setiap kelompok, 2) pemrosesan data; guru memberikan bantuan dan bimbingan seperlunya jika ada kelompok yang mengalami kesulitan dalam menganalisis data yang ada dalam LKPD, 3) penyusunan konjektur; guru mengarahkan siswa untuk menyusun dugaan sementara dari hasil analisis yang dilakukan, 4) pemeriksaan konjektur; pada saat berkeliling mengamati pekerjaan siswa, sekaligus memeriksa LKPD tiap kelompok dan memberikan penjelasan apabila terdapat kesalahan dalam mengerjakan LKPD, 5) verbalisasi konjektur; guru meminta perwakilan dari masingmasing kelompok untuk menjelaskan kembali hasil konjektur yang telah disusun dengan mempersentasikannya di depan kelas, 6) umpan balik; memberikan soal latihan tambahan 
yang berkaitan dengan materi konsep sudut yang terbentuk jika dua garis sejajar dipotong oleh garis lain.

Kegiatan penutup dilakukan peneliti dengan menyampaikan hal-hal yang akan dilakukan pada pertemuan selanjutnya. Selanjutnya guru memberikan Pekerjaan Rumah (PR) sebagai soal latihan tambahan kepada siswa dan kemudian mengajak siswa untuk berdoa bersama. Kemudian pembelajaran ditutup dengan mengucapkan salam.

\section{SARAN}

Berdasarkan hasil penelitian yang dilakukan, maka beberapa saran yang dapat diberikan kepada guru dan peneliti selanjutnya yaitu, pembelajaran dengan menerapkan metode penemuan terbimbing layak dipertimbangkan sebagai alternatif dalam pembelajaran pada materi hubungan antar garis dan sudut, diperlukan kemampuan dalam membimbing siswa yang masih mengalami kesulitan dalam memahami materi sehingga hasil yang peroleh sesuai dengan apa yang diharapkan, Pemikiran yang luas dan mendalam serta kesabaran dan kepekaan terhadap gagasan yang berbeda dari siswa sebaiknya dimiliki oleh seorang pengajar bila menghadapi jumlah siswa yang banyak, sehingga kerusuhan dalam kelas bisa teratasi.

\section{DAFTAR PUSTAKA}

Arikunto, S. (2007). Penelitian Tindakan Kelas. Jakarta: Bumi Aksara.

Cendana, L. (2016). Penerapan Metode Penemuan Terbimbing Untuk Meningkatkan Hasil Belajar Siswa Pada Materi Hubungan Garis dan Sudut di Kelas VIIA SMP Negeri 13 Palu. Skripsi FKIP Universitas Tadulako Palu. Tidak diterbitkan

Departemen Pendidikan Nasional. (2006). Kurukulum Tingkat Satuan Pendidikan (KTSP) 2006 Mata Pelajaran Matematika. Jakarta: Depdiknas

Markaban, (2006) Model Pembelajaran Matematika dengan Pendekatan Penemuan Terbimbing. [Online]. http://p4tkmatematika.Org/download/ppp/PPP Penemuan Terbimbing.pdf, [diakses tanggal 6 juli 2018]

Nurcholis. (2013) Implementasi Metode Penemuan Terbimbing untuk Meningkatkan Hasil Belajar Siswa Pada Materi Penarikan Kesimpulan Logika Matematika di Kelas X A SMA Negeri 9 Palu. Skripsi FKIP Universitas Tadulako. tidak diterbitkan.

Sutrisno. (2012). Efektivitas Pembelajaran Dengan Metode Penemuan Terbimbing Terhadap Pemahaman Konsep Matematis Siswa. Jurnal pendidikan matematika. [online] Vol. 2 (1) halaman [http:fkip.unila.ac. id/ojs/journals/II/ JPMU Vol No4/016Sutrisno.pdf]. [10 Desember 2017]

Suwarsono. (2013). Pengembangan Kreativitas dalam Pembelajaran Matematika pada Kurikulum 2013. [online], math.fkip.uns.ac.id.makalah-utama-vol-1-3.pdf. [03 Agustus 2017]

Trianto. (2009). Mendesain Model Pembelajaran Inovatif-Progresif. Surabaya: Kencana Prenada Media Group. 
Ufi. (2017). Penerapan Model Pembelajaran Penemuan Terbimbing untuk Meningkatkan Hasil Belajar Siswa Kelas VII SMP Negeri 19 Palu dalam Materi Hubungan Antar Garis dan Sudut. Skripsi FKIP Universitas Tadulako Palu. Tidak diterbitkan.

Yulia, (2010). Meningkatkan Hasil Belajar Siswa Melalui Metode Penemuan Terbimbing Pada Materi Luas Permukaan dan Volume Kubus serta Balok di Kelas VIIA SMP Negeri 1 Sindue. Skripsi FKIP Universitas Tadulako Palu. Tidak diterbitkan.

Yusnawan, I. P. A. (2013). Penerapan Metode Penemuan Terbimbing Untuk Meningkatkan Pemahaman Siswa Pada Materi Gradien di Kelas VIII SMP Negeri 9 Palu. [Online]. Jurnal Elektronik Pendidikan Matematika Tadulako.Volume 01 Nomor01.Tersedia:http://jurnal.untad.ac.id/jurnal/index.php/JEPMT/article/downloa d/3095/2168 [10 Desember 2017] 